\title{
Climate future
}

\section{Deciding how to evaluate a cap-and-trade programme raises some thorny questions, says David Goldston.}

S cientists sometimes describe the way human activities are changing the composition of Earth's atmosphere as a giant (and dangerous) experiment: we don't know enough about the complexities of the climate system to fully gauge all of the impacts of the increase in greenhouse-gas levels. Less frequently noted is that the antidote to global climate change is also a giant (although necessary) experiment: we don't know enough about the complexities of the economic system to fully gauge all of the impacts of a cap-and-trade system to limit greenhouse-gas emissions. These uncertainties are reason to pay attention to two little-noticed parts of the climate legislation now beginning to work its way through the US Congress: the section on research, and especially the section on programme evaluation.

Of course, the most noteworthy fact is that climate legislation is moving, although it is too soon to know if it will make it through the House of Representatives and the Senate. It was a watershed event when, on 21 May, the House Committee on Energy and Commerce approved a bill of almost 1,000 pages to cut US greenhouse-gas emissions (see Nature 459, $493 ; 2009)$. This was the first ever vote in the House on a comprehensive climate bill and, more importantly, the first time Congress had worked on climate legislation with a president who would sign it into law. That's why industry groups, including those representing electric utilities and oil refineries, worked out deals with the bill's sponsors, Democrats Henry Waxman of California and Edward Markey of Massachusetts.

What industry wants most from a climate programme is regulatory certainty. Yet to be effective, a bill has to be open to alteration as more is learned about both the climate and the results of regulation. The Waxman-Markey bill includes several sections requiring evaluation of the cap-and-trade programme. Although this sounds simple, it raises some fundamental questions: how often should the programme be reviewed? Who should be examining it? What should they be evaluating? What should happen to their recommendations?

Most other climate bills assign the evaluation either to a government interagency committee or to the National Academy of Sciences. The advantages of a governmental panel are that its members may have first-hand knowledge of

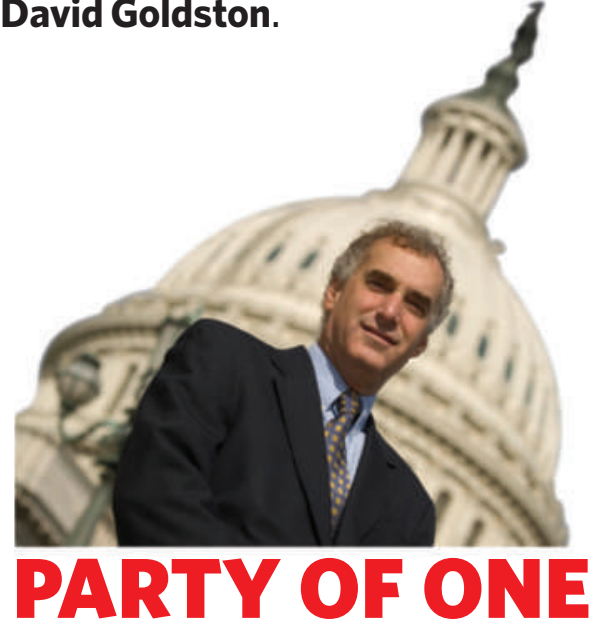

how well emissions monitoring is working and what levels of emissions are being recorded, and that they can appropriately make policy recommendations. The advantages of the academy are its stature and presumed independence, but the assignment can take the academy into areas that strain its expertise and may require it to weigh in on questions that involve values as much as science. There is no one right answer, for example, when deciding how much money society should be willing to spend to fend off a possible consequence of climate change. Moreover, involving the academy in every aspect of the climate debate may erode its ability to act as an 'honest broker' on a range of issues - a vital function that few other institutions can fulfil.

The Waxman-Markey bill has it both ways, requiring the Environmental Protection Agency (EPA) to report to Congress every four years and then having the academy issue a review of that report the following year. The report would be extensive, including looking at US and international emission levels, their impacts and whether the emissions cap should be changed. This mix of report and review may be the best of both worlds, especially if the prospect of academy oversight makes the EPA more meticulous, but it could also set up an overt fight between the academy and an administration, or cause the academy panel to trim its sails to avoid one.

Under the bill, the academy would also provide an additional report every four years on "the emissions reduction potential, commercial viability, market penetration, investment trends and deployment" of technologies that could reduce emissions. Interestingly, the bill requires that academy panel to "include the participation of technical experts from relevant private industry sectors". This is a reasonable idea and indeed perhaps the only way to tap the requisite expertise. But it also raises the spectre of conflict-of-interest charges and points to both how much of a stretch this report may be for the academy and how difficult it is for any report on the topic to be considered objective.

A year after the academy issues its two documents, the bill mandates that the president direct federal agencies "to take appropriate actions identified" in the EPA and academy reports. This verges on requiring the president to follow academy recommendations - a bad idea, given that policy recommendations involve more than science and should not be delegated to an unaccountable panel nominated by the academy. But the most substantial change that could be recommended - altering the overall emissions cap - would require congressional action.

A few scientists and science groups have weighed in on this language (and the committee staff asked me for my views early on without sharing any text), but this aspect of the bill merits fuller discussion - including whether new mechanisms need to be invented for reviews at the intersection of science, technology and policy. Climate regulation is not likely to remain fixed over the 40 years covered in the bill, and how possible changes are laid out for lawmakers may prove to be significant.

One facet of the bill that is likely to be the subject of greater debate in coming months is whether and how it funds research. Although President Barack Obama proposed setting aside US\$15 billion a year for research and development, the Waxman-Markey bill includes only about $\$ 1$ million a year to set up university research centres (although there is more money for technology deployment). Neither the Obama administration nor university lobbyists have pressed this issue yet, but university groups are planning to weigh in as the bill moves forwards. Funding in the Waxman-Markey bill is especially valuable because it would be available without further congressional action; it would not need to pass as part of the annual battles over spending legislation.

It's unsurprising that these provisions have been below the radar so far; the whole bill has received remarkably little front-page coverage. But research and programme evaluation need to be part of the discussion as the bill moves forwards - because no climate legislation can possibly get everything right the first time around.

David Goldston (partyofonecolumn@gmail. com) is a visiting lecturer at Harvard University's Center for the Environment. 